\title{
MENINGKATKAN HASIL BELAJAR SISWA PADA MATA PELAJARAN PKn MELALUI MODEL PEMBELAJARAN LANGSUNG DI KELAS V SD NEGERI NO. 057752
}

\author{
Eridawati \\ Guru Di SD Negeri No. 057752 Kampung Bali \\ Surel : erida_wati@yahoo.com
}

\begin{abstract}
Improving Student Learning Outcomes Lesson In Civic Education With Learning Model Direct Instruction In Class V SD Negeri No. 057752 T.A 2015/2016. This research aims to improve students' learning activities using Direct Instruction learning model in class V SD Negeri No. 057752. These research subjects are 14 students. The study lasted for two cycles can be concluded that 1) The results of student learning through the implementation of the Direct Instruction learning model is based on observations of the two observers increased from the first cycle to the second cycle. 2) Activities of student learning through the implementation of the Direct Instruction learning model increases from the first cycle to the second cycle.
\end{abstract}

Keywords : Learning Direct Instruction, Student Learning Outcomes

\begin{abstract}
Abstrak : Meningkatkan Hasil Belajar Siswa Pada Mata Pelajaran PKn Melalui Model Pembelajaran Langsung Di Kelas V SD Negeri No. 057752 T.A 2015/2016. Penelitian ini bertujuan untuk meningkatkan aktivitas belajar siswa dengan menggunakan model pembelajaran Direct Instruction di kelas V SD Negeri No. 057752. Subjek penelitian ini berjumlah 14 orang siswa. Penelitian berlangsung selama dua siklus dapat disimpulkan bahwa 1) Hasil belajar siswa melalui penerapan model pembelajaran Direct Instruction berdasarkan pengamatan kedua pengamat mengalami peningkatan dari siklus I ke siklus II. 2) Aktivitas belajar siswa melalui penerapan model pembelajaran Direct Instruction meningkat dari siklus I ke siklus II.
\end{abstract}

Kata Kunci : Pembelajaran Direct Instruction, Hasil Belajar Siswa

\section{PENDAHULUAN}

Dalam pembelajaran PKn sebaiknya siswa dilibatkan secara aktif. Selama ini dalam proses penyampaian materi PKn banyak yang kurang dimengerti oleh siswa dan juga tidak memperhatikan taraf berfikir siswa. Padahal dalam usia sekolah dasar proses abstraksi siswa masih perlu dibantu dengan media lain. Untuk itu perlu suatu metode dan strategi dalam kegiatan pembelajaran agar tujuan pembelajaran dapat tercapai.

Dari hasil observasi dan diskusi dengan guru di kelas V SD Negeri No.057752 Kampung Bali, diperoleh bahwa hasil belajar yang diperoleh siswa masih dibawah rata-rata KKM (Kriteria Ketuntasan Minimal) yaitu 70.
Dari jumlah siswa terdapat lebih dari $50 \%$ siswa yang mendapat nilai dibawah KKM. Seharusnya belajar dikatakan tuntas apabila siswa secara keseluruhan mampu mendapatkan nilai diatas nilai KKM yaitu 70. Dengan demikian dapat dikatakan bahwa hasil belajar siswa pada pembelajaran tersebut masih sangat rendah.

Jika permasalahan diatas terus berlanjut maka sangat mengkhawatirkan terhadap dunia pendidikan yang seharusnya menghasilkan manusia yang bermutu. Guru juga harus mewaspadai permasalahan di atas, agar siswa-siswa tidak mendapat nilai yang rendah namun mendapatkan nilai yang memuaskan. Untuk itu diperlukan berbagai upaya untuk mengatasi permasalahan tersebut. 
Salah satu upaya yang dapat dilakukan yakni dengan menggunakan model pembelajaran Langsung.

Model pembelajaran Langsung juga sering disebut belajar melalui observasi, dimana siswa belajar dengan mengamati secara selektif, mengingat dan menirukan tingkah laku gurunya. Pembelajaran dengan model pembelajaran Langsung, guru terlibat aktif dalam mengusung isi pelajaran kepada peserta didik dan mengajarkannya secara langsung kepada seluruh kelas. Model pembelajaran Langsung dimaksudkan untuk menuntaskan dua hasil belajar yaitu penguasaan pengetahuan yang distrukturkan dengan baik dan penguasaan keterampilan.

Berdasarkan latar belakang di atas, maka yang menjadi rumusan masalah dalam penelitian ini adalah; 1) Bagaimana hasil belajar siswa yang diajar dengan menggunakan model pembelajaran Langsung?; 2) Bagaimana aktivitas belajar siswa dengan diterapkannya model pembelajaran Langsung selama KBM?;

Berdasarkan rumusan masalah di atas, maka tujuan penelitian ini adalah untuk; 1) Untuk mengetahui bagaimana peningkatan hasil belajar siswa yang diajar dengan menggunakan model pembelajaran Langsung; 2) Untuk mengetahui bagaimana aktivitas belajar siswa dengan diterapkannya model pembelajaran Langsung;

Menurut Arends dalam Trianto (2007 : 29) pembelajaran langsung adalah salah satu pendekatan mengajar yang dirancang khusus untuk menunjang proses belajar siswa yang berkaitan dengan pengetahuan deklaratif dan pengetahuan prosedural yang terstruktur dengan baik yang dapat diajarkan dengan pola kegiatan yang bertahap, selangkah demi selangkah. Dengan menerapkan model pembelajaran langsung Peneliti harus mendemonstrasikan pengetahuan atau keterampilan yang akan dilatih kepada siswa secara selangkah demi selangkah karena dalam pembelajaran peran Peneliti sangat dominan, maka Peneliti dituntut agar dapat menjadi seorang model yang menarik bagi siswa.

\section{METODE}

Penelitian ini dilakukan di SD Negeri No. 057752 Jalan Kampung Bali, kabupaten Langkat pelaksanaannya pada bulan Februari 2016 sampai dengan Juni 2016.

Subjek dalam penelitian ini adalah seluruh siswa kelas V SD Negeri No. 057752. Pemilihan kelas V dikarenakan peneliti merupakan guru kelas V SD Negeri No. 057752. Banyak subjek penelitian yakni 14 siswa.

Alat pengumpul data dalam penelitian ini adalah: tes hasil belajar untuk mengetahui kemampuan kognitif siswa dan lembar aktivitas siswa.

Penelitian ini berbentuk Penelitian Tindakan Kelas (PTK). PTK pertama kali diperkenalkanoleh psikologi sosial Amerika yang bernama Kurt Lewin pada tahun 1946 (Aqib, 2006 :13). Menurut Lewin dalam Aqib (2006 : 21) menyatakan bahwa dalam satu Siklus terdiri atas empat langkah, yaitu perencanaan (planning), tindakan (acting), observasi (observing) dan refleksi (reflecting).

Metode analisis data pada penelitian ini digunakan metode deskriptif dengan membandingkan hasil belajar siswa sebelum tindakan dengan hasil belajar siswa setelah tindakan.

Langkah-langkah pengolahan data sebagai berikut: 
1) Merekapitulasi nilai pretes sebelum tindakan dan nilai tes akhir siklus I dan siklus II.

2) Menghitung nilai rata-rata atau persentase hasil belajar siswa sebelum dilakukan tindakan dengan hasil belajar setelah dilakukan tindakan pada siklus I dan siklus II untuk mengetahui adanya peningkatan hasil belajar.

Yang menjadi indikator keberhasilan guru mengajar digunakan KKM mata pelajaran PKn di sekolah dengan nilai $\geq 70$ maka disebut tuntas individu, dan bila ada $85 \%$ nilai $\geq 70$ disebut tuntas kelas.

\section{PEMBAHASAN}

Berdasarkan hasil identifikasi dapat diketahui bahwa kelas yang memiliki permasalahan dan kendala-kendala di kelas V. Hal ini ditunjukkan dari banyaknya siswa kelas $\mathrm{V}$ yang belum mencapai standar Kriteria Ketuntasan Minimal (KKM) yang telah ditetapkan oleh pihak sekolah, yaitu 70 untuk mata pelajaran PKn. Pada saat diadakan ulangan harian, kelas $\mathrm{V}$ selalu memiliki nilai rata-rata relatif rendah.

Berdasarkan hasil diskusi bersama pembimbing penelitian dan pendamping penelitian dari Universitas Negeri Medan maka dipilihlah Model pembelajaran Langsung. Dalam model ini guru hanya berperan sebagai mediator, fasilitator, dan pemberi kritik yang bersahabat. Seyogiyanya guru membimbing dan mencerminkan kelompok melalui tiga tahap: (a) tahap pemecahan masalah; (b) tahap pengelolaan kelas; (c) tahap pemaknaan secara perorangan. Ditempuhnya tiga tahapan tersebut, diharapkan proses pembelajaran dapat menghasilkan proses belajar yang lebih baik dan siswa lebih menyeluruh dalam mendalami materi yang disampaikan oleh guru.disajikan pada Tabel.

Tabel Distribusi Hasil Pretes

\begin{tabular}{|c|c|c|}
\hline Nilai & Frekunsi & Rata-rata \\
\hline 40 & 5 & \\
\cline { 1 - 2 } 50 & 7 & \multirow{2}{*}{47.9} \\
\hline 60 & 2 & \\
\cline { 1 - 2 } Jumlah & 14 & \\
\hline
\end{tabular}

Merujuk pada Tabel, nilai terendah untuk pretes adalah 40 dan tertinggi adalah 60 dengan tidak seorang pun mendapat nilai di atas ketuntasan atau ketuntasan klasikal adalah $0 \%$. Nilai rata-rata kelas adalah 47,9. Ini berarti siswa tidak mempersiapkan diri belajar dirumah untuk tiap materi baru sebelum datang ke sekolah.

Hasil Formatif I disajikan dalam Tabel berikut:

Tabel Distribusi Hasil Formatif I

\begin{tabular}{|c|c|c|}
\hline Nilai & Frekuensi & Rata-rata \\
\hline 60 & 4 & \multirow{3}{*}{78,6} \\
\cline { 1 - 2 } 80 & 7 & \\
\cline { 1 - 2 } 100 & 3 & \\
\cline { 1 - 2 } Jumlah & 14 & \\
\hline
\end{tabular}

Merujuk pada Tabel tersebut, nilai terendah formatif I adalah 60 dan tertinggi adalah 100 dengan 10 orang mendapat nilai di bawah kriteria ketuntasan atau ketuntasan klasikal adalah sebesar $71 \%$. Nilai ini berada di bawah kriteria keberhasilan sehingga dapat dikatakan KBM siklus I belum berhasil memberi ketuntasan belajar dalam kelas. Nilai rata-rata kelas adalah 78,6 .

Tabel skor aktivitas belajar diperoleh dari lembar observasi aktivitas. Pengamatan dilakukan oleh dua pengamat selama 40 menit kerja kelompok dalam setiap KBM atau 80 
menit dalam satu siklus. Dengan pengamatan setiap 2 menit, maka nilai maksimum yang mungkin teramati untuk satu kategori aktivitas selama 80 menit adalah 40 kali.

Tabel Skor Aktivitas Belajar Siswa

\begin{tabular}{|c|c|c|c|}
\hline \multicolumn{4}{|c|}{ Siklus I } \\
\hline No & Aktivitas & Skor & Proporsi \\
\hline 1 & $\begin{array}{l}\text { Menulis, } \\
\text { membaca }\end{array}$ & 21,0 & $42 \%$ \\
\hline 2 & Mengerjakan & 15,0 & $30 \%$ \\
\hline 3 & $\begin{array}{l}\text { Bertanya pada } \\
\text { teman }\end{array}$ & 9,0 & $18 \%$ \\
\hline 4 & $\begin{array}{l}\text { Bertanya pada } \\
\text { guru }\end{array}$ & 2,5 & $5 \%$ \\
\hline 5 & $\begin{array}{l}\text { Yang tidak } \\
\text { relevan }\end{array}$ & 2,5 & $5 \%$ \\
\hline & Jumlah & 50 & $100 \%$ \\
\hline
\end{tabular}

Berdasarkan pada tabel pada siklus I rata-rata aktivitas I yakni menulis dan membaca memperoleh proporsi $42 \%$. Aktivitas mengerjakan dalam diskusi mencapai 30\%. Aktivitas bertanya pada teman sebesar $18 \%$. Aktivitas bertanya kepada guru 5\% dan aktivitas yang tidak relevan dengan KBM sebesar 5\%. Nilai-nilai ini memperlihatkan beberapa hal diantaranya, ketika siswa berdiskusi dalam kelompok banyak kelompok yang terlihat bingung dalam pelaksanaannya sehingga peneliti kewalahan melayani pembimbingan tiap kelompok. Sementara beberapa siswa tidak aktif dalam melaksanakan diskusi, siswa tersebut hanya berdiam diri, seolah-olah tidak mau tahu dan hanya melakukan kegiatan menulis dan membaca, meskipun ada beberapa siswa yang aktif dalam berargumen. Dengan kata lain, dari seluruh komponen aktivitas belajar tersebut belum ada satu komponen aktivitas siswa yang nilainya tinggi (belum ada yang mencapai 60\%).
Setelah berakhirnya siklus II, guru memberikan tes yang merupakan Formatif II. Hasil Formatif II disajikan dalam Tabel berikut:

Tabel Distribusi Hasil Formatif II

\begin{tabular}{|c|c|c|}
\hline Nilai & Frekuensi & Rata-rata \\
\hline 60 & 2 & \multirow{2}{*}{87.1} \\
\hline 80 & 5 & \\
\hline 100 & 7 & \\
\cline { 1 - 2 } Jumlah & 14 & \\
\hline
\end{tabular}

Merujuk pada Tabel, nilai terendah untuk formatif II adalah 60 dan tertinggi adalah 100 dengan 2 orang mendapat nilai di bawah kriteria ketuntasan atau ketuntasan klasikal adalah sebesar $87 \%$. Nilai rata-rata kelas adalah 87,1 .

Skor aktivitas belajar diperoleh dari lembar observasi aktivitas. Pengamatan dilakukan oleh dua pengamat selama 40 menit kerja kelompok dalam setiap KBM atau 80 menit dalam satu siklus. Dengan pengamatan setiap 2 menit, maka nilai maksimum yang mungkin teramati untuk satu kategori aktivitas selama 80 menit adalah 40 kali.

Adapun data aktivitas yang diperoleh selama 80 menit pada siklus II adalah sebagai berikut:

Tabel Skor Aktivitas Belajar Siswa Siklus II

\begin{tabular}{|l|l|c|c|}
\hline \multicolumn{4}{|c|}{ Siklus II } \\
\hline No & \multicolumn{1}{|c|}{ Aktivitas } & Skor & Proporsi \\
\hline 1 & $\begin{array}{l}\text { Menulis, } \\
\text { membaca }\end{array}$ & 16,0 & $32 \%$ \\
\hline 2 & Mengerjakan & 21,0 & $42 \%$ \\
\hline 3 & $\begin{array}{l}\text { Bertanya } \\
\text { pada teman }\end{array}$ & 2,5 & $5 \%$ \\
\hline 4 & $\begin{array}{l}\text { Bertanya } \\
\text { pada guru }\end{array}$ & 8,5 & $17 \%$ \\
\hline 5 & $\begin{array}{l}\text { Yang tidak } \\
\text { relevan }\end{array}$ & 2,0 & $4 \%$ \\
\hline
\end{tabular}




\begin{tabular}{|l|l|l|} 
Jumlah & 50 & $100 \%$ \\
\hline
\end{tabular}

Berdasarkan data tabel diperoleh bahwa rata-rata formatif I pada siklus I adalah 78,6 dengan persentase klasikal sebesar $71 \%$. Nilai ini menggambarkan bahwa ketuntasan belajar sudah tercapai karena rata-rata nilai yang diperoleh sudah berada di atas KKM dan sudah mencapai nilai ketuntasan klasikal yang ditetapkan yaitu $85 \%$.

Tercapainya standar ketuntasan tersebut tidak terlepas dari meningkatnya aktivitas belajar siswa. Merujuk pada tabel 4.3, pada siklus I rata-rata aktivitas I yakni menulis dan membaca memperoleh proporsi $32 \%$. Aktivitas mengerjakan dalam diskusi mencapai $42 \%$. Aktivitas bertanya pada teman sebesar 5\%. Aktivitas bertanya kepada guru $17 \%$ dan aktivitas yang tidak relevan dengan KBM sebesar $4 \%$.

Terjadinya peningkatan hasil belajar tersebut dari siklus satu ke siklus berikutnya terkait dengan perbaikanperbaikan pada siklus ke II berdasarkan kelemahan-kelemahan pada siklus I. Akibat perbaikan tersebut berdampak pada aktivitas belajar siswa yang makin baik untuk semua aspek seperti yang tergambar dalam gambar $4.5 \mathrm{di}$ atas. Sehubungan dengan telah tercapainya standar ketuntasan yang ditetapkan melalui Model pembelajaran Langsung, maka pelaksanaan pembelajaran siklus III tidak dilanjutkan lagi.

Untuk pengambilan data-data penelitian ini dibagi menjadi dua siklus yaitu siklus I dan siklus II. Pada siklus I dan siklus II model pembelajaran Langsung.

Melalui Model pembelajaran Langsung siswa menjadi lebih bersemangat dalam mengikuti proses belajar. Pembelajaran Langsung merupakan usaha untuk meningkatkan keaktifan siswa dan mendekatkan jarak antar siswa yang disebabkan adanya perbedaan individu dan tuntutan untuk bekerja dan belajar secara bersama-sama dalam suatu kelompok. Pengajaran dengan model Langsung yaitu siswa dibagi dalam kelompok-kelompok kemudian melaksanakan investigasi materi dan mempresentasikan hasil investigasi.

Berdasarkan nilai formatif (tes tertulis), dan nilai observasi (aktivitas belajar) pada`siklus 2 ini, telah dilakukan beberapa perbaikan pembelajaran antara lain: (a) menyampaikan teknik-teknik berdiskusi/ bertanya, (2) memberikan motivasi kepada siswa untuk turut berpartisipasi dalam timnya serta pentingnya bertanya kepada guru, dan menerapkan teknik bertanya oleh guru khususnya saat terjadinya penyimpangan aktivitas siswa atau saat terjadinya kevakuman siswa dalam kegiatan pembelajaran. memberikan motivasi kepada siswa dengan menginformasikan semua nilainilai yang diperoleh siswa selama siklus I, serta cara-cara belajar yang efektif. Dengan adanya perbaikan-perbaikan tersebut, aktivitas belajar siswa semakin baik pada siklus 2 ini, serta hasil belajar siswa pun turut menjadi lebih baik (tinggi) dan telah memenuhi nilai standar yang telah ditetapkan oleh sekolah. Dengan demikian, pelaksanaan pembelajaran dengan penerapan model pembelajaran Langsung untuk siklus III tidak dilanjutkan lagi.

\section{KESIMPULAN}

Dari hasil kegiatan pembelajaran yang telah dilakukan selama dua siklus, dan berdasarkan seluruh pembahasan serta analisis yang telah dilakukan dapat disimpulkan sebagai berikut: 
1. Dengan menggunakan model pembelajaran Langsung diperoleh hasil belajar siswa dari siklus ke siklus berikutnya mengalami peningkatan. Pada siklus I menunjukkan tuntas individunya sebanyak 10 orang dengan tuntas kelas sebesar $71 \%$. Pada siklus II menunjukkan tuntas individu 12 orang dengan tuntas kelas sebesar $87 \%$. Hasil belajar siswa dengan menerapkan model pembelajaran Langsung formatif I dan formatif II menunjukkan 78,6 dan 87,1, dari data tersebut menunjukkan tuntas sesuai dengan KKM PKn.

2. Data aktivitas siswa menurut pengamatan pada siklus I antara lain menulis/membaca (42\%), bekerja (30\%), bertanya sesama teman $(18 \%)$, bertanya kepada guru (5\%), dan yang tidak relevan dengan KBM (9\%). Data aktivitas siswa menurut pengamatan pada Siklus II antara lain menulis/membaca (32\%), bekerja $(42 \%)$, bertanya sesama teman $(5 \%)$, bertanya kepada guru (17\%), dan yang tidak relevan dengan KBM (4\%).

\section{DAFTAR RUJUKAN}

Arikunto, S. (2002). Dasar-Dasar Evaluasi Pendidikan. Bumi Aksara. Jakarta.

Aqib, Zainal. (2006). Penelitian Tindakan Kelas. Yrama Widya. Bandung.

Harahap, Sermaida Hotmaria. (2015).

$\begin{array}{lr}\text { Penerapan } & \text { Model } \\ \text { Pembelajaran } & \text { Advance } \\ \text { Organizer } & \text { Untuk } \\ \text { Meningkatkan Hasil Belajar } & \text { Belataran } \\ \text { Siswa Pada Mata Pelajaran } & \text { Kimia Di Kelas XI MIA-3 }\end{array}$

Semester Genap SMAN 1

Percut Sei Tuan T.A. 2014/ 2015. UD.Toma.Medan

Ibrahim, M., dkk. (2000). Pembelajaran kooperatif. Universitas Negeri Surabaya. Surabaya.

Lie, A. (2004). Cooperatif Learning Memperaktekkan Cooperatif Learning di Ruang-Ruang Kelas. PT Grasindo. Jakarta.

Syah, M. (2003). Psikologi Pendidikan. Rajagrafindo persada. Jakarta. 